http://dx.doi.org/10.4314/jae.v16i2.1

\title{
Fish Farmers' Perception of Climate change impact on fish production in Delta State, Nigeria
}

\author{
A. Aphunu* and G. O. Nwabeze ${ }^{\star *}$ \\ *Department of Agricultural Extension and Management \\ Delta State Polytechnic, P.M.B. 5, Ozoro. \\ ${ }^{* *}$ National Institute for Freshwater Fisheries Research \\ P.M.B. 6006, New Bussa, Niger State. \\ E-mail:tonyaphunu@yahoo.co.uk; Mobile: +2348030877533
}

\begin{abstract}
Fish farming has great potential for mitigating the decreasing landings from capture fisheries arising from climate change, pollution, overexploitation and use of obnoxious fishing methods. There is strong evidence that the fisheries sub-sector of agriculture is experiencing major challenges and some of these challenges are directly linked to climate change. Therefore, the present study attempts to investigate fish farmers' perception of climate change impact on fish production in Delta State. Respondents in the area perceived climate change factors to include variability of temperature, air humidity and total rainfall. The study further revealed that respondents perceived low yield from fish culture to be a consequence of the negative impact of climate change. This study concluded that there's a need for the active involvement of stakeholders in developing policies relating to climate change mitigation and beneficial response strategies to global warming.
\end{abstract}

Keywords: Climate change, fish farming, impact and perception.

\section{Introduction}

The Intergovernmental Panel on Climate Change (IPPC, 2007) defined climate change as statistically significant variations in climate that persist for an extended period, typically decades or longer. It includes shifts in the frequency and magnitude of sporadic weather events as well as the slow continuous rise in global mean surface temperature.

Climate change is a change in climate that is attributable directly or indirectly to human activities. It affects the atmospheric conditions of the earth thereby leading to global warming. According to Raymond and Victoria (2008), climate change has the potential to affect all natural systems thereby becoming a threat to human 
development and survival socially, politically and economically. A comprehensive summary by the IPCC in 2007 stated that human actions are very likely the cause of global warming; meaning a $90 \%$ or greater probability is attributable to man. The assessment by the IPCC of the scientific evidence suggests that human activities are contributing to climate change and that there has been a discernable human influence on global climate. Various activities carried out by man have varying contributions to the changes in the climatic systems. The burning of coal, oil and natural gas (gas flaring), as well as deforestation and various agricultural and industrial practices, are altering the composition of the atmospheric and are contributing to climate change (www.gerio.org). These human activities lead to increased atmospheric concentration of a number of greenhouse gases, which in turn produce greenhouse effects (www.undp.org).

Climate change is a major challenge to agricultural development in Africa and the world at large. Ziervogel et al (2006) noted that climate change, which is attributable to natural climate cycle and human activities, has adversely affected agricultural productivity in Africa. This is particularly because African agriculture is predominantly rain-fed and hence fundamentally dependent on the vagaries of weather (Watson et al, 1987). Zoellick (2009) stated that, as the planet warms, rain fall patterns shift, and extreme events such as droughts, floods, and forest fires become more frequent. This results in poor and unpredictable yields, thereby making farmers more vulnerable, particularly in Africa (UNFCCC, 2007). Climate change affects agriculture in several ways, one of which is its direct impact on food production. Besides, almost all sectors in agriculture (crop, livestock, pastoralism, fishery, etc) depend on weather and climate whose variability have meant that rural farmers who implement their regular annual farm business plans risk total failure due to climate change effects (Ozor et al, 2010). The risk from climate in Africa, and the rest of the world, includes, rising temperatures and heat waves, shortfalls in water supply/increasing floods arising from shortage/excessive rainfalls, sea level rise, increasing likelihood of conflict and induced environmental and vector borne diseases. These conditions emanating from climate change are bound to compromise agricultural productions (crop, livestock, forest and fishery resources), nutritional and health statuses, trading in agricultural commodities, human settlements (especially of agricultural communities), tourism and recreation among others (Tologbonse et al, 2010).

Climate change has serious implications for global fisheries and aquaculture. Besides the physical and financial drivers, climate is a major driver that enhances the aquaculture sector growth and sustainability. The variability of temperature, air humidity and total rainfall shows negative signs to aquaculture production in ponds system. These problems have contributed to major loss of production and increase in socio-economic and income vulnerability among farmers. The small scale or individual farmers are among the highest vulnerable to climate change (Tan, 1998). According to F.A.O (2009), global fish production came to about 144 million metric tones (mmt) comprising $92 \mathrm{mmt}$ from capture and over $51 \mathrm{mmt}$ from 
aquaculture. Production of $92 \mathrm{mmt}$ from capture represents a decrease of $2.2 \mathrm{mmt}$ compared to figures for 2005. Considering Nigeria's enormous water resources, human capital and other natural endowments, the Federal Department of Fisheries estimated fish production of over 1.7mmt comprising 201,300mt (offshore fisheries), 288,200mt (inland fisheries) and 1,180,215mt (aquaculture) (George, 2010). Constraints to increased fish production in Nigeria include, among others, climate change effects (including sea level rise, coastal erosion and flooding, increase in environmental temperatures, and wind storms).

Climate change requires the development of natural resources management strategies that ensures the sustainable use of soil and water, halt biodiversity decline and deal with emerging issues such as demand for renewable energy. Societies must therefore respond by both minimizing further warming (by reducing the concentration of greenhouse gases in the atmosphere) and finding ways to adapt to the impacts that warming will bring, such as shifting precipitation regimes, more frequent and severe extreme weather events, and sea-level rise (Nzeadike, Egbule, Chukwuone and Agu, 2011). Adaptation is understood to include efforts to adjust to ongoing and potential effects of climate change (Mani et al, 2008). Within the context of climate change, adaptation include the actions people take in response to, or in anticipation of changing climate conditions in order to reduce adverse impacts or take advantage of any opportunities that may arise.

This paper discusses the perception of fish farmers on the impact of climate change on fish production as well as strategies adopted to cope with the impacts in Delta State. The specific objectives were to:

(i) describe the socio-economic characteristics of fish farmers in the state;

(ii) determine fish farmers' level of climate change awareness;

(iii) examine sources of information on climate change;

(iv) determine fish farmers' perception of impact of climate change on fish production;

(v) ascertain fish farmers' coping strategies of reducing/alleviating the effect of climate change, and

(vi) determine the relationship between perception of climate change effect and other independent variables.

\section{Methodology}

The study was conducted in Delta State, South-South geopolitical zone of Nigeria. The State lies between longitudes $5^{\circ} 00^{\prime}$ and $6^{\circ} 45^{\prime}$ East and latitude $5^{\circ} 00^{\prime}$ and $6^{0} .30^{\prime}$ North. The state is generally low-lying without hills but with a wide coastal belt interlaced with rivulets, streams and rivers which form part of the Niger Delta. The average annual rainfall for the state varies from 2700 millimeters in the coastal area and 1900 millimeters in the northern fringes. Temperature is high, 
ranging between $28^{\circ} \mathrm{C}$ and $34^{\circ} \mathrm{C}$ with an average of $30^{\circ} \mathrm{C}$. The distribution of vegetation varies from mangrove swamp along the coast to fresh water swamp forests and a derived savannah in the north.

\section{Sampling Procedure and Data Collection}

Fish farmers in the state constituted the population for the study. A multi-stage random sampling technique was used to select respondents. The state is divided into three agricultural zones namely - Delta North zone, Delta Central zone and Delta South zone. Two agricultural zones (Delta Central and Delta South) were purposively selected because of their natural endowment for fish production. Two Local Government Areas (LGAs) were randomly selected from each of the two zones. For Delta Central zone, Uvwie and Ughelli North LGAs were randomly selected while Isoko-South and Warri-South were selected from Delta South Zone. Two town communities were also randomly selected from each LGA to give a total of eight town communities. They include Ekpan, Ugboroke, Ekuigbo, Ughelli, Igbide, Aviara, Ubeji and Ugbuawen. Ten fish farmers were then purposively selected from each of the town community. This gave a sample size of 80 .

Data for the study were collected through a semi-structured interview schedule. In order to characterize the respondents on their socio-economic status, educational level, fish farm experience, number of ponds owned, membership of social groups, household size and average annual income, were ascertained. In ascertaining perceived impact of climate change on fish production, a four-point Likert-type scale with options of strongly agree, agree, disagree and strongly disagree with nominal values of $4,3,2$ and 1 respectively was used to obtain responses from fish farmers. Also, to determine strategies adopted by fish farmers to reduce the effects of climate change, farmers were agreed to tick options from a list of various mitigation and adaptation options obtained from literature, expert opinions and observations. Data were analyzed using both descriptive and influential statistics. Objectives one, two and three were analyzed using frequency and mean scores. While objectives four and five were analyzed using mean scores. The inferential statistics used to determine the relationships between the dependent and independent variables was Pearson Correlation Coefficient.

\section{Results and Discussion}

\section{Socio-economic Characteristics}

Results in Table 1 show that majority (78.8\%) of the respondents were males while $21.3 \%$ were females. This indicates that more males are engaged in fish farming than females. The finding agrees with that of George (2010) and Ogunlade (2007), who found out that more males were involved in fish farming than women in their study areas. The male dominance implies the laborious nature of fish farming operations which are very tedious for females to handle. Results also reveal that $27.5 \%$ of the respondents were between the age bracket of 31 and 40 years. The mean age was 39.4 years. This shows that they are still young and 
are in their active productive years and can still actively adopt effective measures for cushioning the impacts of climate change. Data in Table 1 also reveal that majority $(76.3 \%)$ of the respondents were married. This shows that the gender roles in fish production and climate change perception can be effectively distributed among the men and women. Further results in Table 1 show that majority $(45 \%)$ of the respondents had tertiary education, closely followed by those with secondary education (42.5\%). It ahs been reported by Agwu and Anyanwu (1996) that increase in educational status of farmers positively influence their perception and adoption of improved technologies and practices. Again, Table 1 shows that majority (65\%) of the respondents had between 1-5 years fish farming experience. This indicate that majority of the respondents are new entrants into fish farming and could affect their knowledge and experience of climate change impact in fish farming in the area. This is also likely to have effects on their knowledge of mitigation and adaptive measures on climate change. It is also revealed in Table 1 that majority (73.8\%) of the respondents have between 1 and 5 fish ponds, which shows that they are small scale fish farmers for the purpose of augmenting household incomes. Majority (43.8\%) of them belonged to fish farmers Association for the purpose of credit and information accessibilities. Table 1 further shows that majority of the respondents had family sizes of between 1 and 5 persons in their households. The average household size was 5 members. This funding indicates a fairly large family size with the implication that more family labour will be readily available. Igben (1988) reported that large household size was an obvious advantage in terms of labour supply. Finally, results in Table 1 revealed that a little more than half $(51.3 \%)$ of the respondents received less than N50, 000.00 average monthly income from fish farming. This implies that they are small scale fish farmers who operated at small scale level with the consequent low income level. 
TABLE 1: Socio-economic characteristics of respondents $(n=80)$

\begin{tabular}{|c|c|c|c|}
\hline \multirow{2}{*}{\multicolumn{4}{|c|}{$\begin{array}{l}\text { Variables } \\
\text { Sex }\end{array}$}} \\
\hline & & & \\
\hline Male & 63 & 78.8 & \\
\hline Female & 17 & 21.3 & \\
\hline \multicolumn{4}{|l|}{ Age } \\
\hline $21-30$ years & 28 & 35.0 & \\
\hline $31-40$ years & 22 & 27.5 & \\
\hline $41-50$ years & 12 & 15.0 & \\
\hline $\begin{array}{l}39.4 \\
51-60 \text { vears }\end{array}$ & & & \\
\hline $51-60$ years & 11 & 13.8 & \\
\hline Above 60 years & 7 & 8.8 & \\
\hline \multicolumn{4}{|l|}{ Marital status } \\
\hline $\begin{array}{l}\text { Single } \\
\text { Married }\end{array}$ & 18 & 22.5 & \\
\hline $\begin{array}{l}\text { Married } \\
\text { Divorced }\end{array}$ & $\begin{array}{r}61 \\
1\end{array}$ & $\begin{array}{r}16.3 \\
13\end{array}$ & \\
\hline \multicolumn{4}{|l|}{ Level of Education } \\
\hline No formal education & 2 & 2.5 & \\
\hline Primary education & 8 & 10.0 & \\
\hline Secondary education & 34 & 42.5 & \\
\hline Tertiary education & 36 & 45.0 & \\
\hline \multicolumn{4}{|l|}{ Fish farming experience } \\
\hline $1-5$ years & 52 & 65.0 & \\
\hline $\begin{array}{c}6-10 \text { years } \\
5.4\end{array}$ & 17 & 21.3 & \\
\hline \multirow{2}{*}{\multicolumn{4}{|c|}{$\begin{array}{l}\text { Above } 10 \text { years } \\
\text { Number of Ponds }\end{array}$}} \\
\hline & & & \\
\hline $\begin{array}{l}1-5 \\
6-10\end{array}$ & 11 & 13.8 & \\
\hline Above 10 & 10 & 12.5 & \\
\hline \multicolumn{4}{|c|}{ Membership of Associations } \\
\hline Co-operative societies & 14 & 17.5 & \\
\hline Fish farmers' Association & 35 & 43.8 & \\
\hline Monthly contributions & 5 & 6.3 & \\
\hline None & 26 & 32.5 & \\
\hline \multicolumn{4}{|l|}{ Size of household } \\
\hline $1-5$ & 36 & 45.0 & \\
\hline $6-10$ & 24 & 30.0 & 5 \\
\hline Above 10 & 20 & 25.0 & \\
\hline \multicolumn{4}{|l|}{ Income } \\
\hline Less than N50,000.00 & 41 & 51.3 & \\
\hline N50,001-100,000.00 & 16 & 20.0 & \\
\hline N100,001-200,000.00 & 10 & 12.5 & \\
\hline $\mathrm{N} 200,001-300,000.00$ & 4 & 5.0 & \\
\hline Above N300,000.00 & 9 & 11.3 & \\
\hline
\end{tabular}

Source: Field survey, 2011 


\section{Fish Farmers' Awareness of climate change}

Results of the survey on fish farmers' awareness of climate change (Table 2) indicate that $75 \%$ of the respondents were aware of climate change impacts on their fish farming activities and on their lives. However, nearly $77 \%$ of respondents actually know little or nothing about climate change and its impacts. Specifically, it was found that $47.5 \%$ of respondents indicated that they know little about the phenomenon while $31.3 \%$ stated that they do not know about climate change at all. On the other hand, about $11.3 \%$ of respondents indicated that they know about climate change impacts to a reasonable extent while only $10 \%$ of respondents claimed to be very knowledgeable about climate change impacts. The mean $(\mathbf{x})$ of the extent of awareness (knowledge) on climate change is 2.0, which implies a low level of awareness in climate change impact. This result is line with the reports of Nzeadike et al, (2011) that the level of awareness of local communities on climate change impacts was still low in the Niger Delta region of Nigeria.

TABLE 2

\section{Distribution of respondents on awareness of climate change impacts}

$\begin{array}{ll}\text { Variables } & \text { Percentage } \\ \text { Mean } & \end{array}$

\section{Awareness}

Yes

No

\section{Extent of knowledge}

Don't know

31.2

Know little

47.5

Reasonable extent

11.3

2.0

Great extent

10.0

Source: Field survey, 2011

\section{Sources of information on climate change}

Table 3 shows that the main source of information on climate change was through personal experience (33.8\%), followed by Radio/Television (21.3\%) and friends/neighbours (18.8\%). The finding is in line with that of George (2010) where personal contacts, family and friends were the main sources of information on climate change. Similarly, Tologbonse et al (2010) found out that the most important information source on climate change was personal experience followed by radio and television. Farmers' knowledge on climate change through personal experience was probably due to the fact that their livelihood seems to be seriously 
threatened. Results in Table 3 also showed that extension agents (1.3\%) were the least source of information on climate change in the area. This has implication for extension administration and policy making since knowledge of climate change impacts is related to the availability of information on the phenomenon. Extension agents are regarded as the customary source of dependable information to farmers.

TABLE 3

Sources of information on climate change to fish farmers

\begin{tabular}{lc}
\hline Sources & Percentage \\
\hline Extension workers & 1.3 \\
Friends/neighbours & 18.8 \\
Internet & 7.5 \\
Personal experience & 33.8 \\
Newspapers & 2.5 \\
Radio/Television & 21.3 \\
None & 15.0
\end{tabular}

Source: Field survey, 2011

\section{Perception of the impacts of climate change}

Fish farmers' perception of the impacts of climate change is the extent of their agreement to which variables such as high rainfall, massive flood, food insecurity and hunger, poor harvest, extinction of plant and animal species, etc represented their awareness level of climate change. Results in Table 4 show the mean response of fish farmers on their perception of climate change impacts. The result shows that respondents were of the general opinion that climate change has caused drastic change in weather condition (3.04); destruction of property (3.06); increased incidence of flooding (2.86); high temperatures and heat waves (2.64); excessive sunshine (2.56); poor harvest of fish (especially during spawning for fingerlings production) (2.54) and increase in food insecurity and hunger (2.50). However, respondents did not believe that climate change caused increased harvest of fish (2.11); increased incidence of drought (2.29); increased cost of fish production (2.34) or reduced the cost of fish production (2.214). The findings is in line with that of George (2010) that farmers perceived climate change effects from sustained changes over time in environmental temperatures, rainfall intensity and pattern and also wind variability. Dewit and Stankiewicz (2006) predicted that significant negative impacts will be felt across 25 percent of Africa's inland aquatic ecosystems by 2100 . Results of this study confirmed that negative impacts of climate change are being experienced by fish farmers. 
TABLE 4

Perception of impacts of Climate Change

\begin{tabular}{lcc}
\hline Variables & Mean & Std. Deviation \\
\hline Drastic change in weather condition & 3.04 & 0.906 \\
Poor harvest of fish & 2.54 & 0.941 \\
Destruction of property resulting from heavy & & \\
wind storm & 3.06 & 0.932 \\
Excessive sunshine & 2.56 & 0.809 \\
Increased incidence of flooding & 2.86 & 1.847 \\
Increased incidence of drought & 2.29 & 0.860 \\
High temperatures and heat waves & 2.64 & 0.767 \\
Increased harvest of fish & 2.11 & 0.675 \\
Increased productivity of some fish species & 2.45 & 0.727 \\
Increased fish disease infestation & 2.56 & 0.726 \\
Increased cost of fish production & 2.34 & 0.728 \\
Reduced cost of fish production & 2.24 & 0.621 \\
Food insecurity and hunger & 2.50 & 0.857 \\
& &
\end{tabular}

Source: Field survey, 2011

\section{Strategies to reduce/alleviate the effects of climate change on fish production}

Different strategies have been adopted by fish farmers in different parts of the state for climate change adaptation. Table 5 shows the percentage of respondents that adopted different strategies for climate change adaptation. About $85 \%$ of respondents favoured seeking/listening to information about climate change; $80 \%$ have adopted strategies such as use of tarpaulin/tank ponds during dry weathers, about $70 \%$ adapt by adjusting time of stocking while $60 \%$ said they stock fish species that are more favoured by climate change. Others include erecting cover/shades over ponds (57.5\%) and digging boreholes/wells to supply water during dry weathers. 
TABLE 5

Strategies to cope with the impacts of Climate Change

\begin{tabular}{|c|c|c|}
\hline Strategies & Yes (\%) & No (\%) \\
\hline Erecting cover/shades over ponds especially in dry & 57.5 & 42.6 \\
\hline weather & 38.8 & 61.3 \\
\hline Build ponds close to water sources & 56.3 & 43.8 \\
\hline Dig bore holes/wells to supply water during dry seasons & 38.8 & 58.8 \\
\hline Build embankments to prevent flood water & 67.5 & 32.5 \\
\hline Adjustment in the time of stocking & 48.8 & 51.3 \\
\hline Stocking of quick maturing fish species & & \\
\hline $\begin{array}{l}\text { Use of indoor fish production facilities e.g. circulatory } \\
\text { system }\end{array}$ & 10.0 & 90.0 \\
\hline $\begin{array}{l}\text { Procurement of weather/water monitoring kits e.g. } \\
\text { thermometer }\end{array}$ & 85.0 & 15.0 \\
\hline $\begin{array}{l}\text { Seeking/listening to information about climate change } \\
\text { Stocking fish snecies that are more favoured by climate }\end{array}$ & 60.0 & 40.0 \\
\hline $\begin{array}{l}\text { change } \\
\text { Other strategies adopted e.g. building concrete/tarpaulin } \\
\text { ponds, preventive treatment of fish, e.t.c. }\end{array}$ & 80.0 & 20.0 \\
\hline
\end{tabular}

\section{Relationship between perception of climate change impact and other variables}

The result of the Correlation analysis in Table 6 indicate that there was a significant relationship between perception of climate change impacts and the following variables namely: number of fish ponds $(r=0.256 ; p<0.05)$; membership of associations $(r=-0.258 ; p<0.05)$; income $(r=0.259 ; p<0.05)$; extent of knowledge $(r=0.266 ; p<0.05)$ and strategies adopted to cope with effects of climate change $(r=0.551 ; p<0.01)$. The number of fish ponds owned represents the level of investment in fish farming. Those with higher number of fish ponds are more likely to perceive climate change impact more since their livelihood source is affected. On the extent of knowledge, the higher the knowledge the more a respondent is likely to perceive climate change impact to be significant on fish production. The perception of risk is important in identifying the best application of risk management practice. It is believed that coping strategies to combat the impacts of climate change in order to ensure improved and sustainable livelihood of fish farmers depends on their knowledge, attitude, practices and belief systems. 
TABLE 6

\section{Summary of the relationship between perception of climate change and other independent variables}

\begin{tabular}{|c|c|c|c|}
\hline Variable & $\begin{array}{l}\text { Correlation } \\
\text { Coefficient }\end{array}$ & $p$-value & Remark \\
\hline Age & -0.460 & 0.685 & Not significant \\
\hline Marital status & 0.183 & 0.105 & " \\
\hline Educational level & -0.200 & 0.076 & $"$ \\
\hline Fish farming experience & 0.101 & 0.372 & " \\
\hline Number of ponds & $0.256^{*}$ & 0.022 & Significant \\
\hline Membership of Association & $-0.258^{*}$ & 0.021 & " \\
\hline House hold size & 0.047 & 0.677 & Not significant \\
\hline Income level & $0.259^{*}$ & 0.020 & Significant \\
\hline Knowledge & $0.266^{*}$ & 0.017 & " \\
\hline Strategies adopted to cope & $0.551^{* *}$ & 0.000 & " \\
\hline
\end{tabular}

${ }^{*}$ Significant at 5\% $(p<0.05) ;{ }^{* *}$ Significant at 1\% $(p<0.01)$

\section{Conclusion and Recommendation}

Climate change is perhaps the most serious environmental threat to fish production in the Niger Delta region of Nigeria. The study confirms that, though the farmers were aware of the phenomenon, their level of knowledge about the impacts of climate change was low. The farmers indicated relying mostly on personal experience rather than on the mass media or extension agents as their main source of information. It was also evident that the farmers have applied some coping strategies such as seeking information about climate change, adjustment of stocking period, use of tarpaulin/concrete ponds, e.t.c. There is need therefore, for a multi-media enlightenment campaign of the effects and possible adaptation strategies of climate change, to reach all fish farmers, using the available extension structures on ground by all stakeholders. The vast potentials of the mass media should be tapped by policy makers to disseminate climate change information and create more awareness about causes and consequences of climate change as well as strategies for climate change adaptation. Also, efforts should be geared towards identifying and compiling indigenous adaptive strategies 
to climate change that fish farmers may have used over the years as an approach to overall food security in the Niger Delta region.

\section{References}

Agwu, E.A. and Anyanwu, A.C. (1996). Socio-cultural and Environmental Constraints in Implementing the NALDA Programme in South eastern Nigeria. Acase study of Abia and Enugu State. Journal of Agriculture and Education, Vol. 2, pp.68-72.

De Wit, M. and Stankiewics, J. (2006). Changes in surface water supply across Africa with predicted change. Science, 311: 1917-1921.

Food and Agriculture Organization-F.A.O (2009). State of World Fisheries and Aquaculture (SOFIA), 2008.

George, F. O. A (2010). Indigenous and Emerging Technologies for climate change Adaptation in Aquaculture and Fisheries. Journal of Sustainable Development, Vol.7, No.2, 34-42.

Igben, M.S. (1988). Farmers Capability Profile. In: M.S. Igben (ed) .The Nigerian Farmer and Agricultural Institution. An Assessment of NISER Ibadan, Nigeria. Pp. 657-692.

Intergovernmental Panel on Climate Change-IPCC (2007). Climate change Impacts, adaptations and vulnerability. In: Parry, M.C., Canzien, O.F., Palutikot, J.P., van der Linden, Paul, J. and Hanson, C. (eds.). Contribution of Working group II to the $4^{\text {th }}$ Assessment Report of the IPCC. Cambridge: University Press, Cambridge.

Mani, M., Markandya, A and Ipe, V. (2008). Climate Change: Adaptation and Mitigation in development PROGRAMMES: A practical guide. Washington, D.C: World Bank.

Nzeadibe, T.C., Egbule, C.L., Chukwuone, N.A. and Agu, V.C. (2011). Climate Change Awareness and Adaptation in the Niger Delta Region of Nigeria. African Technology Policy Studies Network. Working Paper Series/No. 57.

Ogunlade, I. (2007). Backyard fish farmers Information needs in Osun State, Nigeria. Proceedings, Africa Association of Agricultural Economists Conference held in Accra, Ghana. Pp. 165-169.

Ozor, N., Madukwe, M.C., Onokala, P.C., Enete, A., Garforth, C.J., Eboh, E., Ujah, O. and Amaechina, E. (2010). A Framework for Agricultural Adaptation to Climate Change in Southern Nigeria. A Development Partnership in Higher Education (DelPHE) 326 Project Executive Summary supported by DFID and implemented by the British Council, Enugu; African Institute for Applied Economics. 
Tan, C.K. (1998). Overview of Aquaculture in Malaysia. Occasional Publication No. 9. Kaula Lumpur: Malaysian Fisheries Society.

Tologbonse, E.B., Auta, S.J., Bidoli, T.D., Jaliya, M.M., Onu, R.O. and Issa, F.O. (2010). Farmer's Percption of the Effects of Climate Change and Coping Strategies in Three Agro-Ecological Zonnes of Nigeria. Journal of Agricultural Extension, Vol. 14 (1), June. Pp. 144-156.

United Nations Framework Convention on Climate Change (UNFCCC) (2007). Climate Change Impact, Vulnerabilities and Adaptation in Developing Countries. UNFCCC Secretariat, Martin-Luther King-Straat 853175 Bonn, Germany. www.unfccc.int

Watson, R.T., Zinyowera, M.C. Moses, R.H. (1997). The regional impacts of climate change: An assessment of vulnerability. A special report of IPCC Working Group II. Published for the International Panel on Climate Change. Available online: http://www.ipcc.ch. Assessed on $10^{\text {th }}$ November, 2011.

Ziervogel, G., Nyong, B., Osman, C., Conde, S.C. and Dowing, T. (2006). Climate variability and change: implications for household food security. Assessment of Impacts and Adaptations for Climate Change (AIACC) Working Paper No. 20, January 2006. The AIACC Project Office, International Start Secretariat, Washington DC, USA.

Zoellick, R.B. (2009). Climate Smart Future. The Nation Newspapers. Vintage Press Limited, Lagos, Nigeria. P. 18.

http://dx.doi.org/10.4314/jae.v16i2.2 